\title{
MANAJEMEN SUMBER DAYA MANUSIA DI STASIUN TELEVISI LOKAL RADAR TASIKMALAYA TV
}

\author{
Rangga Saptya Mohamad Permana ${ }^{1}$, Jimi N. Mahameruaji ${ }^{1}$ \\ ${ }^{1}$ Universitas Padjadjaran
}

\begin{abstract}
ABSTRAK
Ketika kita berbicara dalam konteks media, maka sebuah manajemen media yang baik adalah manajemen media yang dapat memanfaatkan unsur-unsur manajemen yang dimilikinya secara efektif dan efisien. Adapun unsur-unsur manajemen itu terdiri dari Material (Produk), Market (Pasar), Method (Manajemen), Man (Manusia), Machine (Sarana), dan Money (Modal), yang biasa disingkat dengan 6M. Dari keenam unsur tersebut, salah satu unsur yang dapat membuat sebuah stasiun televisi bertahan adalah manajemen sumber daya manusia (SDM) yang baik. Dengan manajemen SDM yang baik, stasiun televisi dapat meiliki SDM yang berkualitas sehingga stasiun televisi tersebut dapat bersaing dengan performa maksimal, baik itu dengan sesama stasiun televisi atau dengan media platform lainnya. Metode penelitian yang digunakan dalam riset ini adalah metode penelitian kualitatif dengan menggunakan desain deskriptif-kualitatif. Dalam artikel ini, penulis berusaha untuk memaparkan dan memusatkan perhatian pada bagaimana manajemen SDM di Radar Tasikmalaya TV dilaksanakan, dengan metode pengumpulan data menggunakan metode wawancara, observasi, dan telaah dokumen. Berdasarkan hasil riset, manajemen SDM yang dilaksanakan di Radar Tasikmalaya TV meliputi tahapan rekrutmen pegawai, penilaian produktivitas pegawai, kepemimpinan dan cara memotivasi dari atasan, serta jenjang karier.
\end{abstract}

Kata-kata Kunci: Manajemen; SDM; Televisi; Radar Tasikmalaya TV

\section{HUMAN RESOURCES MANAGEMENT IN LOCAL TELEVISION STATION RADAR TASIKMALAYA TV}

\begin{abstract}
When we speak in the context of the media, a good media management is a media management that can utilize the elements of management it possesses effectively and efficiently. The management elements consist of Material (Product), Market (Market), Method (Management), Man (Human), Machine (Tools), and Money (Capital), commonly abbreviated as $6 \mathrm{M}$. Of the six elements, one element that can make a television station survive is good human resource (HR) management. With a good human resource management, television stations can have qualified human resources so that the television stations can compete with the maximum performance, be it with fellow television stations or with other media platforms. The research method used in this research is qualitative research method by using descriptive-qualitative design. In this article, the author tries to describe and focus on how HR management in Radar Tasikmalaya TV is implemented, with data collection method using interview method, observation, and document review. Based on the results of research, human resource management conducted in Radar Tasikmalaya TV covers the stages of employee recruitment, employee productivity assessment, leadership and how to motivate from managers, as well as career ladder.
\end{abstract}

Keywords: Management; HR; Television; Radar Tasikmalaya TV

Korespondensi: Rangga Saptya Mohamad Permana. Universitas Padjadjaran, Jl. Raya Bandung-

Sumedang KM. 21. Email: ranggasaptyamp@gmail.com 


\section{PENDAHULUAN}

Menurut Gerbner (dalam Ardianto, dkk., 2007: 3) "Mass communication is the technologically and institutionally based production and distribution of the most broadly shared continuous flow of messages in industrial societies". (Komunikasi massa adalah produksi dan distribusi yang berlandaskan teknologi dan lembaga dari arus pesan yang kontinyu serta paling luas dimiliki orang dalam masyarakat industri). Komunikasi massa juga bisa didefinisikan dalam tiga ciri (Wright, dalam Severin dan Tankard, 2008: 4): (1) Komunikasi massa diarahkan kepada audiens yang relatif besar, heterogen, dan anonim; (2) Pesan-pesan yang disebarkan secara umum, sering dijadwalkan untuk bisa mencapai sebanyak mungkin anggota audiens secara serempak dan sifatnya sementara; dan (3) Komunikator cenderung berada atau beroperasi dalam sebuah organisasi yang kompleks yang mungkin membutuhkan biaya yang besar.

Pada paragraf di atas, Gerbner dan Wright mencantumkan kata lembaga dan organisasi pada definisi komunikasi yang mereka utarakan. Jadi jelas, sebuah komunikasi massa harus disampaikan melalui sebuah lembaga, dalam hal ini sebuah media massa. Media massa sendiri terbagi menjadi media elektronik, media cetak, dan media yang mulai dari awal abad milenium mengisi keseharian umat manusia di dunia, yaitu media online atau internet.

Karena kita sedang berbicara dalam konteks media, maka sebuah manajemen media yang baik adalah manajemen media yang dapat memanfaatkan unsur-unsur manajemen yang dimilikinya secara efektif dan efisien. Adapun unsur-unsur manajemen itu terdiri dari Material (Produk), Market (Pasar), Method (Manajemen), Man (Manusia), Machine (Sarana), dan Money (Modal), yang biasa disingkat dengan 6M. Pemanfaatan unsur-unsur manajemen secara maksimal dibutuhkan oleh semua lembaga/organisasi, termasuk oleh sebuah stasiun televisi, karena bila unsur-unsur manajemen ini tidak bisa dimanfaatkan secara maksimal, maka pencapaian tujuan akan lebih sulit untuk diwujudkan.

Mary Parker Follet (1997) (dalam Sule \& Saefullah, 2012: 5) mendefinisikan manajemen sebagai "seni mendapatkan sesuatu/ menyelesaikan sesuatu dengan memberdayakan orang-orang" (management is the art of getting things done through people). Definisi ini menunjukkan bahwa tugas manajemen tidak saja melakukan kegiatan sistematis dalam rangka pencapaian tujuan, tetapi juga merupakan seni dalam memahami perilaku orang lain sehingga dapat diarahkan kepada pencapaian tujuan. Follet sendiri menganjurkan pentingnya manajemen memahami peran dan fungsi manusia secara utuh, dan dia meyakini perlunya sebuah organisasi untuk lebih demokratis dalam memandang pekerja, termasuk juga para manajernya.

Dengan kata lain, bila penulis mengacu pada definisi ini, cara seni memandang manajemen media adalah ketika individuindividu dalam sebuah institusi media massa melaksanakan pekerjaannya melalui 
hubungannya dengan individu lain di dalam institusi media massa yang bersangkutan. Individu-individu tersebut bisa tumbuh dan berkembang melalui hubungannya dengan individu lain di dalam institusi media massa tersebut.

$$
\text { Menurut Hasibuan (1991) (dalam }
$$
Suprapto, 2009: 124) manajemen adalah ilmu dan seni mengatur proses pemanfaatan sumber daya manusia dan sumber-sumber daya lainnya secara efektif dan efisien untuk mencapai tujuan tertentu. Dalam definisi ini, jelas behwa seni terdapat di dalam manajemen. Mengapa? Karena sebagai seni, manajemen adalah "bagaimana" cara memimpin sekelompok orang atau tim kerja di dalam sebuah organisasi.

Menurut definisi dari Hasibuan di atas, ada kata “mengatur”. Yang mengatur, memimpin dan mengelola individu-individu dalam sebuah organisasi adalah seorang manajer. Dalam aspek-aspek seperti perencanaan, kepemimpinan, komunikasi, dan segala sesuatu yang menyangkut unsur manusia, bagaimanapun juga seorang manajer harus mampu menggunakan pendekatan artistik. Di sinilah unsur seni dalam mengelola sebuah institusi media massa berperan; karena manusia adalah makhluk kreatif, berperasaan, dan yang terpenting, adalah makhluk sosial yang selalu membutuhkan interaksi dengan manusia lain.

Dalam konteks manajemen media, organisasi tersebut adalah institusi media massa; bisa itu institusi media cetak, media elektronik, atau bahkan media baru seperti internet. Seluruh institusi media massa tersebut membutuhkan sebuah manajemen karena di dalamnya mengandung unsur manusia; karena institusi media massa merupakan sebuah kerangka kerja dari suatu proses manajemen yang menunjukkan adanya pembagian tugas (job description) dan memenuhi persyaratan (spesifikasi teknis) tertentu yang jelas bagi setiap personel dalam melakukan pekerjaannya masing-masing dalam sebuah instansi media massa.

Salah satu jenis media massa elektronik adalah televisi. Televisi memiliki beberapa keunggulan dibandingkan dengan media massa jenis lain, salah satu diantaranya adalah sifatnya yang audiovisual. Dengan sifat audiovisualnya ini, televisi dapat memberikan pengaruh yang sangat kuat dalam memengaruhi sikap, perilaku, dan tindakan khalayaknya, terutama bagi khalayak yang pasif. Oleh karena itulah, televisi terus mengalami perkembangan dari zaman ke zaman, mulai dari televisi hitam-putih sampai kini ada jenis televisi dengan gambar digital bahkan juga tersambung dengan internet.

Televisi yang kita tonton mengandung program-program yang beragam, mulai dari program news, film, kuis, talk show, hingga program-program olahraga. Program-program tersebut tentu dikelola oleh sebuah lembaga, dalam hal ini sebuah stasiun televisi. Sebuah stasiun televisi tentunya harus memiliki tujuan yang jelas dalam lembaganya. Menurut Peter Pringle (dalam Suprapto, 2009: 146) pada umumnya tujuan media penyiaran dapat dibagi ke dalam tiga hal, yaitu tujuan ekonomi, tujuan pelayanan, dan tujuan personal. Ketiga tujuan ini dapat dicapai melalui sebuah manajemen yang baik. 
MANAJEMEN SUMBER DAYA MANUSIA

Peran sebagai seorang pemimpin, pengatur, dan pengelola sebuah organisasi dipegang oleh seorang manajer. Seorang manajer harus memiliki keterampilan dasar manajerial dalam mengelola sebuah organisasi.

Robert L. Katz (dalam Suprapto, 2009: 135) menggolongkan keterampilan dasar manajer tersebut menjadi tiga kategori, yaitu teknis (technical), kemanusiaan (human), dan konseptual (conceptual). Karena seni memandang manajemen media melalui unsur manusia yang terkandung di dalamnya, maka seni berkaitan erat dengan cara seorang manajer memimpin dan mengatur individu-individu lain dalam mengelola sebuah institusi media massa, juga cara dia berhubungan dengan para pekerjanya. Seorang manajer harus mampu bekerja sama dengan orang lain, dan kemampuan tersebut disebut dengan human skill.

Seluruh stasiun televisi pastinya menggunakan pendekatan seni ini dalam mengelola segala sesuatu yang mengandung unsur manusia, baik itu stasiun televisi dengan skala internasional, regional, nasional, bahkan lokal. Salah satu televisi swasta lokal yang kini eksis mengudara di Jawa Barat, tepatnya di Tasikmalaya, adalah Radar Tasikmalaya TV (RT TV), yang gelombang siarannya bisa diterima di beberapa wilayah, antara lain Tasikmalaya, Garut, Ciamis, Banjar, Pangandaran, hingga ke Cilacap. Sebagai salah satu institusi media massa, RT TV juga tentunya memiliki unsur manusia yang harus dikelola di dalamnya.
Seperti yang telah disebutkan di atas, dalam sebuah manajemen media, terdapat unsur 6M, yaitu Material (Produk), Market (Pasar), Method (Manajemen), Man (Manusia), Machine (Sarana), dan Money (Modal). Unsur seni dalam sebuah manajemen pada umumnya dan manajemen media khususnya, terkandung pada unsur Man (Manusia). Jadi, lingkup manajemen media dalam riset ini ada pada lingkup internal manajemen. Berdasarkan paparan di atas, penulis tertarik untuk meneliti dan mengetahui bagaimana manajemen diterapkan dalam pengelolaan manusia dalam manajemen RT TV melalui hubunganhubungan antar manusia dalam perusahaan, yang dapat terwujud dari sistem rekrutmen pegawai, penilaian produktivitas pegawai, kepemimpinan dan pemberian motivasi dari General Manager (GM) RT TV kepada para pekerjanya, serta jenjang karir pegawai.

\section{Televisi}

Dari semua media komunikasi yang ada, televisilah yang paling berpengaruh pada kehidupan manusia. Televisi mengalami perkembangan secara dramatis, terutama melalui pertumbuhan televisi kabel. Transmisi program televisi kabel menjangkau seluruh pelosok negeri dengan bantuan satelit dan diterima langsung pada layar televisi di rumah dengan menggunakan wire atau microwave (wireless cables) yang membuka tambahan saluran televisi bagi pemirsa. Televisi tambah marak lagi setelah dikembangkannya Direct 
Broadcast Satellite (DBS) (Ardianto, dkk., 2007: 134).

Kini sedikitnya terdapat lima metode penyampaian program televisi yang telah dikembangkan (dalam Ardianto, dkk., 2007: 135), yaitu : (1) Over-the-air reception of network and local station program. Kualitas gambar yang masih kuno ditingkatkan dengan High Density Television (HDTV); (2) Cable. Program disampaikan melalui satelit ke sistem kabel lokal, kemudian didistribusikan ke rumahrumah dengan kabel di bawah tanah atau dengan tambahan kabel, sistem cable standard dibakukan tahun 1990-an; (3) Digital Cable. Ini bagian dari information super highway. Dahulu sistem kabel lokal dan telepon untuk pelanggan dalam jumlah besar memakai kabel kuno. Sekarang diganti dengan kabel serat optik yang ditanam di bawah tanah tetapi memiliki kapasitas lebih tinggi. Kabel serat optik ini dapat memuat lebih dari 500 saluran. Sistem ini memungkinkan terjadinya komunikasi televisi dua arah. Instalasi kabel serat optik ini termasuk program nasional yang memerlukan biaya sangat besar; (4) Wireless Cable. Sejumlah sistem kabel menyampaikan program bagi pelanggan yang menggunakan transmisi microwave (gelombang pendek) meskipun kabel ini di bawah tanah. Metode ini mengurangi biaya serat optik, tetapi memerlukan peralatan khusus dalam penerimaan program; dan (5) Direct Broadcast Satellite $\quad(D B S)$. Program-program ditransmisikan oleh satelit langsung dengan menggnakan piringan yang berdiameter 18 inci ditempatkan di atap rumah atau di Indonesia dikenal dengan istilah parabola. Metode ini merupakan terobosan dalam sistem televisi kabel, yang dimulai di Amerika Serikat sejak tahun 1994.

Ardianto, dkk., (2007: 137) mengatakan bahwa setidaknya ada tiga karakteristik televisi yang membedakannya dengan media massa lain, yaitu: (1) Audiovisual: televisi memiliki kelebihan, yakni dapat didengar sekaligus dapat dilihat; (2) Berpikir dalam gambar (think in picture): ada dua tahap yang dilakukan dalam proses berpikir dalam gambar, yaitu visualisasi (visualization) dan penggambaran (picturization). Visualisasi adalah menerjemahkan kata-kata yang mengandung gagasan yang menjadi gambar secara individual, sedangkan penggambaran adalah kegiatan merangkai gambar-gambar individual sedemikian rupa, sehingga kontinuitasnya mengandung makna tertentu; dan

Pengoperasian lebih kompleks: banyak sekali unsur yang terlibat dalam sebuah proses produksi siaran televisi, baik itu jumlah pekerja maupun peralatan yang digunakan. Hal itulah yang membuat televisi memiliki sistem pengoperasian yang lebih kompleks daripada media massa lainnya.

Pada dasarnya proses produksi suatu acara televisi ada tiga tahapan (pre productionproduction-post production) sesuai dengan perkembangannya saat ini ada yang berpendapat bahwa proses produksi ada empat tahapan (pre production/tahap perencanaan-rehearsal/set up persiapan secara teknis/tahapan persiapan akhir--post production/tahapan penyelesaian). Tahapan- 
tahapan sebuah proses produksi siaran televisi meliputi: (1) Pra produksi: perencanaan/tahap persiapan awal; (2) Rehearsal/set up: setting peralatan, dekorasi/property, latihan camera work, pemain, general rehearsal; (3) Produksi: pelaksanaan shooting di lapangan; dan (4) Pasca produksi: penyelesaian produksi (editing/manipulating/mixing,

dubbing/illustration, titling, previewing, revisi).

\section{Stasiun Televisi Lokal}

Stasiun penyiaran televisi lokal merupakan stasiun penyiaran televisi dengan wilayah siaran terkecil yang mencakup satu wilayah kota atau kabupaten. Undang-undang Penyiaran No. 32 Tahun 2002, pasal 31 ayat 5 menyatakan, bahwa stasiun penyiaran lokal dapat didirikan di lokasi tertentu dalam wilayah negara Republik Indonesia dengan wilayah jangkauan siaran terbatas pada lokasi tersebut. Ini berarti syarat atau kriteria suatu stasiun televisi dikategorikan sebagai penyiaran televisi lokal adalah lokasi sudah ditentukan dan jangkauan siarannya terbatas.

\section{Radar Tasikmalaya TV (RT TV)}

RT TV adalah sebuah stasiun televisi swasta lokal yang beroperasi di Kota Tasikmalaya. Televisi lokal ini mengudara pada gelombang 56 UHF. Gelombang siaran RT TV mencakup wilayah Tasikmalaya, Ciamis, Banjar, Garut, Pangandaran, hingga sebagian besar Cilacap. Komposisi siaran RT TV adalah $25 \%$ informasi, $20 \%$ berita, 30\% hiburan, $10 \%$ pendidikan, 5\% agama, dan 10\% iklan.
Program-program RT TV yang termasuk ke dalam hard news adalah Radar Siang (12.00 WIB), Radar Sore (18.30 WIB), dan Radar Malam (21.30 WIB). Pada akhir pekan, disiarkan program Radar Sepekan, yang ditayangkan setiap hari Minggu, pukul 18.30 WIB. Ada pula program Reportase Kriminal, yang ditayangkan setiap hari Senin, pukul 19.00 WIB. Sedangkan program-program RT TV yang termasuk ke dalam soft news adalah Pos Ronda, Cahaya Hati, Ceria (Cerdas, Riang, Gembira), Susur Wisata, Konsul Kesehatan, Wanita-wanita dan Pintu Hati. RT TV juga menyiarkan program-program hiburan yang mayoritas merupakan program hiburan yang berbau musik. Program-program hiburan tersebut antara lain Karaoke Dangdut, IndieSession, Top Request, Top Request Weekend, Tembang Pasundan (Tepas), dan Kompilasi.

Pegawai inti RT TV berjumlah 30 orang, sudah termasuk General Manager (GM). Jadi, berdasarkan kuantitas, RT TV termasuk ke dalam organisasi penyiaran kecil. Jabatanjabatan inti yang ada di dalam struktur organisasi RT TV antara lain GM, Manajer Program, Manajer Iklan, Manajer Studio, dan bagian Administrasi. Strategi jangka pendek yang coba dirancang oleh manajemen RT TV adalah lebih berorientasi pada audiens dan lebih meningkatkan kualitas program yang ditayangkan. Untuk strategi jangka panjang, manajemen RT TV masih berupaya untuk bersaing dengan media multi-platform di era digital ini. 


\section{Manajemen}

Manajemen mencakup kegiatan untuk mencapai tujuan, dilakukan oleh individuindividu yang menyumbangkan upayanya yang terbaik melalui tindakan-tindakan yang telah ditetapkan sebelumnya. Hal tersebut meliputi pengetahuan tentang apa yang harus mereka lakukan, menetapkan cara bagaimana melakukannya, memahami bagaimana mereka harus melakukannya dan mengukur efektivitas dari usaha-usaha mereka (Terry, 2012: 9).

Sedangkan Nickels, McHugh and McHugh (1997, dalam Sule \& Saefullah, 2012: 6) mengatakan bahwa manajemen adalah sebuah proses yang dilakukan untuk mewujudkan tujuan organisasi melalui rangkaian kegiatan berupa perencanaan, pengorganisasian, pengarahan, dan pengendalian orang-orang serta sumber daya organisasi lainnya (the process used to accomplish organizational goals through planning, organizing, directing, and controlling people and other organizational resources). Berdasarkan pengertian ini, maka dapat disimpulkan bahwa manajemen pada dasarnya merupakan seni atau proses dalam menyelesaikan sesuatu yang terkait dengan pencapaian tujuan. Dalam penyelesaian akan sesuatu tersebut, terdapat tiga faktor yang terlibat: (1) Adanya penggunaan sumber daya organisasi, baik sumber daya manusia, maupun faktor-faktor produksi lainnya. Atau sebagaimana menurut Griffin, sumber daya tersebut meliputi sumber daya manusia, sumber daya alam, sumber daya keuangan, serta informasi; (2) Adanya proses yang bertahap dari mulai perencanaan, pengorganisasian, pengerahan dan pengimplementasian, hingga pengendalian dan pengawasan; dan (3) Adanya seni dalam menyelesaikan pekerjaan.

Morissan (2011: 135) menyebutkan bahwa ada tiga alasan utama mengapa manajemen diperlukan, yaitu: (1) Untuk mencapai tujuan: Manajemen dibutuhkan untuk mencapai tujuan organisasi; (2) Untuk menjaga keseimbangan: Manajemen dibutuhkan untuk menjaga keseimbangan antara tujuan-tujuan, sasaran-sasaran dan kegiatan-kegiatan yang saling bertentangan dari pihak-pihak yang berkepentingan dalam organisasi; dan (3) Untuk mencapai efisiensi dan efektivitas. Suatu kerja organisasi dapat diukur dengan banyak cara yang berbeda; salah satu cara yang umum yang banyak digunakan adalah dengan menggunakan patokan efisiensi dan efektivitas.

\section{Manajer}

Manajer adalah orang yang melakukan kegiatan manajemen. Lebih lengkap lagi, manajer adalah individu yang bertanggungjawab secara langsung untuk memastikan kegiatan dalam sebuah organisasi dijalankan bersama para anggota dari organisasi (Sule \& Saefullah, 2012: 18). Mengadopsi peran manajer dari Schermerchon yang mengutip pendapat Mintzberg (dalam Suprapto, 2009: 134) bahwa manajer, terutama manajer komunikasi, memiliki tiga peran utama, yaitu: (1) Peran interpersonal (interpersonal roles): Menyangkut interaksi dengan pihak dalam maupun luar organisasi; (2) Peran informasional (informational roles): Menyangkut pemberian, 
penerimaan, dan penganalisisan informasi; dan

(3) Peran pengambilan keputusan (decisional roles): Menyangkut pemanfaatan informasi utnuk membuat keputusan dalam memecahkan permasalahan atau melihat kesempatan yang ada.

Robert L. Katz (dalam Suprapto, 2009: 135) menggolongkan keterampilan dasar manajer menjadi tiga kategori, yaitu: (1) Keterampilan Teknis (Technical Skill): Kemampuan untuk menggunakan keahlian khusus dalam melakukan tugas tertentu; (2) Keterampilan Kemanusiaan (Human Skill): Kemampuan untuk bekerja sama dengan orang lain. Ada tiga falsafah dalam human skill ini, yaitu mutual interest (kepentingan bersama), human dignity (harga diri), dan perbedaanperbedaan individu; dan (3) Keterampilan Konseptual (Conceptual Skill): Berhubungan dengan konsep dalam proses manajerial.

Menurut Morissan (2011: 137) pada media penyiaran — dan juga perusahaan lainnya pada umumnya-posisi manajer biasanya terdiri dari tiga tingkatan (level), yaitu: (1) Manajer tingkat bawah (lower level manager), yaitu manajer pada tingkat ini bertugas mengawasi secara dekat pekerjaan rutin karyawan yang berada di bawah naungannya. Manajer tingkat bawah bertanggung jawab kepada manajer tingkat menengah; (2) Manajer tingkat menengah (middle manager), yaitu manajer yang bertanggung jawab untuk melaksanakan kegiatan tertentu sebagai bagian dari proses untuk mencapai tujuan utama perusahaan. Manajemen menengah dapat meliputi beberapa tingkatan dalam suatu organisasi. Para manajer menengah membawahi dan mengarahkan kegiatan-kegiatan para manajer lainnya dan kadang-kadang juga karyawan operasional. Sebutan lain bagi manajer menengah adalah manajer departemen, kepala pengawas (superintendents) dan sebagainya; dan (3) Manajer puncak (top manager) yaitu manajer yang mengoordinasikan kegiatan perusahaan serta memberikan arahan dan petunjuk umum untuk mencapai tujuan perusahaan. Klasifikasi manajer tertinggi ini terdiri dari sekelompok kecil eksekutif. Manajemen puncak bertanggung jawab atas keseluruhan manajemen organisasi. Sebutan khas bagi manajer puncak adalah direktur atau presiden direktur.

\section{General Manager (GM; Manajer Umum)}

Pimpinan tertinggi suatu stasiun penyiaran biasanya disebut General Manager (GM; manajer umum), pada stasiun besar berskala nasional, pimpinan tertinggi ini disebut juga direktur utama. Seorang GM bertanggung jawab untuk seluruh bagian stasiun penyiaran, namun ia mempunyai dua tanggung jawab utama, yaitu: (1) menetapkan sasaran (target) pemasaran; dan (2) mengendalikan pengeluaran (Morissan, 2011: 153).

Pada media penyiaran, GM bertanggung jawab kepada pemilik dan pemegang saham dalam melaksanakan koordinasi sumber daya yang ada (manusia dan barang) sedemikian rupa sehingga tujuan media penyiaran bersangkutan 
dapat tercapai. GM pada dasarnya bertanggung jawab dalam setiap aspek operasional suatu stasiun penyiaran. Dalam melaksanakan tanggung jawab manajemennya, GM melaksanakan empat fungsi dasar, yaitu perencanaan (planning), pengorganisasian (organizing), pengarahan dan memberikan pengaruh (directing/influencing) serta pengawasan (controlling) (Morissan, 2011: 138).

\section{Kepemimpinan}

Stoner, Freeman, dan Gilbert (1995, dalam Sule \& Saefullah, 2012: 255) mendefinisikan kepemimpinan sebagai proses dalam mengarahkan dan memengaruhi para anggota dalam hal berbagai aktivitas yang harus dilakukan (the process of directing and influencing the task-related activities of group member). Lebih jauh lagi, Griffin (dalam Sule \& Saefullah, 2012: 255) membagi pengertian kepemimpinan menjadi dua konsep, yaitu sebagai proses dan sebagai atribut. Sebagai proses, kepemimpinan difokuskan kepada apa yang dilakukan oleh para pemimpin, yaitu proses di mana para pemimpin menggunakan pengaruhnya untuk memperjelas tujuan organisasi bagi para pegawai, bawahan, atau yang dipimpinnya, memotivasi mereka untuk mencaai tujuan tersebut, serta membantu menciptakan budaya produktif dalam organisasi. Adapun dari sisi atribut, kepemimpinan adalah kumpulan karakteristik yang harus dimiliki oleh seorang pemimpin.

Stoner juga menambahkan definisi kepemimpinan manajerial. Menurut Stoner (dalam Morissan, 2011: 165), kepemimpinan manajerial dapat didefinisikan sebagai suatu proses pengarahan dan pemberian pengaruh pada kegiatan-kegiatan dari sekelompok anggota yang saling berhubungan tugasnya. Pemberian pengaruh maksudnya adalah pemimpin dapat memengaruhi bagaimana bawahan melaksanakan perintahnya.

Tujuan kepemimpinan, di sisi lain, adalah membantu orang untuk menegakkan kembali, mempertahankan dan meningkatkan motivasi mereka. Jadi, pemimpin adalah orang yang membantu orang lain untuk memperoleh hasilhasil yang diinginkan. Pemimpin bertindak dengan cara-cara memperlancar produktivitas, moral tinggi, respons yang energik, kecakapan kerja yang berkualitas, komitmen, efisiensi, sedikit kelemahan, kepuasan, kehadiran, dan kesinambungan dalam organisasi (Pace \& Faules, 2006: 276).

Terry (2012: 155) menyusun beberapa jenis kepemimpinan, antara lain kepemimpinan menurut situasinya, kepemimpinan menurut perilaku-pribadi, kepemimpinan yang tugassentris atau pekerja-sentris, kepemimpinan pribadi, kepemimpinan demokratis, kepemimpinan otoriter, kepemimpinan paternalistis, dan kepemimpinan "alami". Terry juga menambahkan bahwa terdapat lima keterampilan yang penting untuk dikembangkan oleh seorang pemimpin, yaitu objektivitas terhadap hubungan dan perilaku manusia, mampu berkomunikasi, wibawa, kesadaran diri, dan mengajar.

\section{Motivasi}


Menurut Franch dan Raven, sebagaimana dikutip Stoner, Freeman, dan Gilbert (dalam Sule \& Saefullah, 2012: 235), motivasi adalah sesuatu yang mendorong seseorang untuk menunjukkan perilaku tertentu (motivation is the set of forces that cause people to behave in certain ways). Stoner, Freeman, dan Gilbert (dalam Sule \& Saefullah, 2012: 237) juga mengemukakan bahwa paling tidak terdapat tiga pendekatan yang telah dikenal dalam dunia manajemen, yaitu pendekatan tradisional atau dikenal sebagai traditional model of motivation theory, pendekatan relasi manusia atau human relation model, dan pendekatan sumber daya manusia atau human resources model.

Menurut Terry (2012: 130), motivasi dapat diartikan sebagai mengusahakan supaya seseorang dapat menyelesaikan pekerjaan dengan semangat karena ia ingin mengerjakannya. Tugas seorang manajer adalah menciptakan kondisi-kondisi kerja yang akan membangkitkan dan mempertahankan keinginan untuk bersemangat itu. Untuk itu, seorang manajer perlu mengenal orang dan memiliki keterampilan untuk mengetahui perilaku mereka. Manusia memiliki motivasi yang berbeda; tergantung dari banyak faktor seperti kepribadian, ambisi, pendidikan dan usia.

Terry (2012: 130) juga mengatakan bahwa ada tiga pendekatan penting yang menyangkut motivasi, yaitu: (1) Pendekatan "Partnership": Pendekatan ini mengasumsikan bahwa pegawai tidak menyukai pekerjaan, namun mereka akan melaksanakannya dengan baik apabila mereka mempunyai perasaan bahwa mereka berpartisipasi dalam hasil-hasil perusahaan. Oleh karena itu, untuk menumbuhkan motivasi, manajer perlu bersikap ramah dan penuh pertimbangan, menghindari konflik-konflik kepegawaian, menciptakan kondisi kerja yang nyaman dan apabila perusahaan makmur, maka pegawainya pun harus makmur; (2) Pendekatan Produktivitas: Pendekatan ini menekankan pada imbalan yang didasarkan pada produktivitas kerja. Pemberian tugas menjadi spesifik dan tingkat upah atau gaji ditetapkan sesuai prestasinya. Kebijaksanaan-kebijaksanaan perusahaan diikuti dengan seksama; tugas-tugas diuraikan dengan jelas, pelaksanaan tugas dihitung dengan tepat dan pelaksanaan tugas yang baik diberi imbalan yang memadai. Dasar pemikiran pendekatan ini adalah bahwa orang yang melaksanakan suatu pekerjaan dan diberi imbalan berusaha untuk mengulang kembali pekerjaan tersebut. Sebaliknya, apabila pegawai dikenakan hukuman sebagai akibat dari tindakannya, ia tidak akan berusaha untuk mengulanginya lagi; dan (3) Pendekatan Pemuasan-Kebutuhan: Pendekatan ini menekankan pada suatu usaha untuk memberikan perhatian terhadap kebutuhan manusiawi dan memberi kepuasan melalui kondisi-kondisi kerja. Perhatian tersebut tidak ditujukan pada kepuasan manusiawi, tetapi pada kepuasan yang diperjuangkan oleh mereka. Manusia selalu memiliki kebutuhan; apabila satu kebutuhan sudah terpenuhi, timbul yang lain lagi sebagai penggantinya. Akibatnya, 
manusia terus mencari jalan untuk memenuhi kebutuhannya. Pada pendekatan ini, maka cara dan suasana kerja ditetapkan mengikuti keterampilan kerja pegawai supaya ada perimbangan antar kepuasan dan kebutuhan, serta hubungan antar anggota kelompok dan pekerjaannya. Tujuannya ialah membangkitkan suatu kemauan untuk mengerjakan tugas, sehingga dapat diselesaikan dengan baik dan memberi kepuasan kepada yang bersangkutan dan perusahaan.

\section{METODE PENELITIAN}

Metode penelitian yang digunakan dalam riset ini adalah metode penelitian kualitatif dengan menggunakan desain deskriptifkualitatif. Metode penelitian kualitatif adalah metode penelitian yang berlandaskan pada filsafat postpositivisme, digunakan untuk meneliti pada kondisi obyek yang alamiah, di mana peneliti adalah sebagai instrumen kunci, teknik pengumpulan data dilakukan secara triangulasi (gabungan), analisis data bersifat induktif/kualitatif dan hasil penelitian kualitatif lebih menekankan makna daripada generalisasi (Sugiyono, 2010: 9).

Penelitian deskriptif hanyalah memaparkan situasi atau peristiwa. Penelitian ini tidak mencari atau menjelaskan hubungan, tidak menguji hipotesis atau membuat prediksi (Rakhmat, 2012: 24). Sedangkan format deskriptif kualitatif pada umumnya dilakukan pada penelitian dalam bentuk studi kasus. Format deskriptif kualitatif studi kasus tidak memiliki ciri seperti air (menyebar di permukaan), tetapi memusatkan diri pada suatu unit tertentu dari berbagai fenomena (Bungin, 2011: 68). Jadi, dalam riset ini, penulis berusaha untuk memaparkan dan memusatkan perhatian pada bagaimana manajemen SDM di Radar Tasikmalaya TV dilaksanakan dengan metode pengumpulan data menggunakan metode wawancara, observasi dan telaah dokumen.

Esterberg (2002) dalam Sugiyono (2010: 231), mendefinisikan wawancara sebagai berikut: a meeting of two persons to exchange information and idea through question and responses, resulting in communication and joint construction of meaning about a particular topic (Wawancara merupakan pertemuan dua orang untuk bertukar informasi dan ide melalui tanya jawab, sehingga dapat dikonstruksikan makna dalam suatu topik tertentu). Untuk menggali informasi-informasi yang dibutuhkan, penulis telah mewawancarai salah seorang manajer divisi di RT TV, yaitu Djalu Dwi Martanto, atau biasa dipanggil Pak Anto. Wawancara dilakukan dengan teknik wawancara mendalam, di mana data-data penting telah penulis dapatkan dari beliau. Tentu saja data yang penulis dapatkan dari hasil wawancara ini sangat berguna untuk menunjang riset ini.

Sutrisno Hadi (1986, dalam Sugiyono, 2010: 145) mengemukakan bahwa observasi merupakan suatu proses yang kompleks, suatu proses yang tersusun dari pelbagai proses biologis dan psikologis. Dua di antara yang terpenting adalah proses-proses pengamatan dan ingatan. Teknik pengumpulan data ini dimaksudkan untuk memperoleh data pelengkap yang dibutuhkan dalam penyusunan 
MANAJEMEN SUMBER DAYA MANUSIA

DI STASIUN TELEVISI LOKAL RADAR TASIKMALAYA TV

karya ilmiah ini dengan cara terjun secara langsung ke lapangan (field research). Maksud penulis terjun ke lapangan adalah penulis melakukan kunjungan ke kantor dan studio Radar Tasikmalaya TV untuk mengamati pelaksanaan manajemen SDM dalam lingkungan organisasi RT TV, terutama dari segi kepemimpinan general manajer (GM) dan cara dia memotivasi para pekerjanya.

Dalam hal dokumen, Bogdan (dalam Sugiyono, 2010: 240) menyatakan "in most tradition of qualitative research, the phrase personal documentation is used broadly to refer to any forst person narative produced by an individual which describes his or her own actions, experience and belief'. Teknik pengumpulan data dengan dokumentasi atau telaah dokumen dilakukan oleh penulis untuk memperoleh data tambahan. Teknik ini dilakukan oleh penulis sebelum terjun ke lapangan, ketika proses riset di lapangan, dan setelah riset dilakukan. Penulis mengumpulkan data dan informasi dari berbagai sumber tertulis yang dapat membantu dalam melakukan riset ini. Penulis mengumpulkan, membaca, dan menelaah data yang berbentuk tulisan dan gambar dari berbagai sumber tertulis mengenai manajemen, manajemen media penyiaran, manajemen SDM, kepemimpinan dan motivasi.

\section{HASIL DAN PEMBAHASAN}

\section{Rekruitmen Pegawai Radar Tasikmalaya TV (RT TV)}

Sistem rekruitmen di RT TV dilimpahkan pada manajer bidang masing- masing. Dengan kata lain, bila sebuah bagian membutuhkan pegawai baru, sang manajer akan mendiskusikannya dulu dengan General Manager (GM), lalu biasanya GM memberikan wewenang pada manajer yang membutuhkan pegawai tersebut untuk melakukan seleksi. Yang jelas, persyaratan minimal utnuk menjadi pegawai di RT TV harus memiliki gelar S1, baik itu di bagian program \& produksi, iklan, studio, atau administrasi.

Dalam seleksinya, manajemen RT TV mengadakan tes tertulis, tes praktik dan wawancara. Yang jelas, calon pegawai yang lamarannya diterima dan mengikuti seleksi harus memiliki kemampuan praktis yang dapat dipakai di bidang yang diinginkannya. Pelamar tidak harus berasal dari jurusan yang berhubungan dengan bidang penyiaran, asalkan dia memiliki kualifikasi yang dibutuhkan oleh bidang yang sedang mencari pegawai. Seperti yang tertuang dalam kutipan wawancara dengan Anto (manajer divisi RT TV) berikut ini:

"Bagusnya sih sesuai bidang ya. Misalnya, kalau bagian program atau produksi sedang membutuhkan pegawai, ya dia juga harus punya kualifikasi di bidang itu. Misalnya, kalau mau jadi seorang reporter atau wartawan, dia harus punya dasar jurnalistik sekaligus punya kemampuan mengoperasikan kamera video, minimal handycam lah. Kalau dia ingin kerja di bagian promosi atau program, dia harus bisa mengoperasikan software editing video dan desain. Tapi nggak sesuai bidang juga nggak apa-apa, asalkan dia punya kualifikasi yang kita butuhkan." 
Produktivitas Pekerja Radar Tasikmalaya TV (RT TV)

Produktivitas pekerja di RT TV dinilai berdasarkan karya yang dihasilkannya. Pekerja di RT TV bisa dikatakan produktif apabila ia berhasil memenuhi target perusahaan. Misalnya, jika seorang wartawan diwajibkan meliput tiga berita per hari, jika ia bisa melakukannya terus menerus secara stabil selama satu bulan, maka ia termasuk wartawan yang produktif.

\section{Kepemimpinan General Manager (GM)}

\section{Radar Tasikmalaya TV (RT TV)}

Berdasarkan wawancara yang telah dilakukan, ternyata GM di RT TV sangat menjunjung tinggi hubungan manusiawi ketika menghadapi para pekerjanya, sehingga terjalin sebuah rasa kekeluargaan yang tinggi antara dia, para manajer divisi dan para pekerja. Bisa dibilang, dalam memimpin para pekerjanya, GM RT TV menggunakan pendekatan hubungan kerja kemanusiaan.

Pendekatan hubungan kerja kemanusiaan berpangkal tolak dari pendirian bahwa di dalam organisasi yang di dalamnya beranggotakan lebih dari seorang, pasti melibatkan antar hubungan di antara mereka (Sutarto, 1987: 258). Pendekatan ini sesuai dengan yang dilakukan GM RT TV, di mana ia mengutamakan peranan penting kebutuhan pekerjanya, motivasi, dan hubungan informal yang hangat. Sang GM sadar bahwa para individu di dalam manajemen RT TV bisa bekerja dengan baik apabila ia membangun sebuah hubungan yang baik di antara mereka. GM di RT TV juga menekankan pola kepemimpinan yang demokratis; di mana para pekerjanya bisa menyempaikan pendapat secara terbuka untuk meraih tujuan bersama.

Bila dilihat dari jenis kepemimpinan yang diutarakan George R. Terry, GM RT TV termasuk ke dalam jenis kepemimpinan pekerja-sentris, di mana ia peka terhadap kebutuhan psikologis pekerjanya dan mengedepankan hubungan antar manusia yang kuat. Pengambilan keputusan dilakukan melalui partisipasi dan para manajer divisi dianggap sebagai koordinator dan stimulator gagasan. Dengan sumber daya manusia yang hanya berjumlah 30 orang (termasuk dia), GM dapat mengenal karakteristik personal para manajer divisi juga para pekerjanya. Dengan modal tersebut, dia dapat memilih jenis kepemimpinan ini.

Gaya kepemimpinan seseorang berdasarkan pada beberapa asumsi mengenai manusia dan apa yang memotivasi mereka. McGregor (1967, dalam Pace \& Faules, 2006: 277) menentukan dua perangkat asumsi atau pendapat bipolar yang cenderung dipakai oleh para pemimpin mengenai orang lain. Kedua jenis asumsi ini disebut Teori $\mathrm{X}$ dan Teori $\mathrm{Y}$. Seorang pemimpin yang berpegang pada Teori $\mathrm{X}$ akan menganggap orang sebagai suatu alat produksi, dimotivasikan oleh ketakutan akan hukuman atau oleh kebutuhannya akan uang dan rasa aman. Pimpinan yang memandang pegawai dengan cara seperti ini, cenderung mengawasi mereka dengan ketat, membuat dan menjalankan aturan dengan keras, dan menggunakan ancaman hukuman sebagai alat untuk memotivasi mereka. Sedangkan 
pemimpin yang mendasari gagasan atau tindakannya dengan Teori Y beranggapan bahwa pegawai itu ambisius, penuh motivasi, dan dapat mengendalikan diri mereka sendiri. Pimpinan percaya bahwa pegawai bisa menikmati tugas-tugas yang mereka emban tanpa ada pengaruh/rangsangan eksternal. Pimpinan juga percaya bahwa pegawainya bisa memecahkan persoalan dan mengambil keputusan secara mandiri.

Bila merujuk pada asumsi Teori $\mathrm{X}$ dan Teori Y ini, penulis dapat melihat bahwa GM RT TV termasuk ke dalam pimpinan yang menganut asumsi dari Teori $\mathrm{Y}$, di mana ia menganggap para pekerjanya adalah para individu aktif yang bisa menikmati pekerjaanya, bersedia memberikan kontribusi pada perusahaan, bersedia menerima tanggung jawab, dapat membuat keputusan bagi diri sendiri, dan mampu menanggulangi masalahmasalah yang terjadi.

Hasil wawancara juga menunjukkan bahwa para manajer divisi menilai GM adalah orang yang sangat demokratis. Dalam meeting internal yang biasa dilakukan jajaran manajerial setiap bulan, GM amat menghargai keputusan yang logis dan kreatif sebagai hasil pengertian dan kesepakatan para manajer divisi. GM selalu mendengarkan dan mencari gagasan, pendapat dan sikap yang berbeda dari yang dianutnya. GM memiliki keyakinan kuat mengenai apa-apa yang harus dilakukan, tetapi memberi respon pada gagasan para manajer divisi yang logis dengan mengubah pendapatnya. Bila terjadi konflik, GM selalu mencoba memeriksa alasan-
ELEVISI LOKAL RADAR TASIKMALAYA TV
alasan timbulnya perbedaan dan mencari penyebab utamanya. Dalam perilaku kepemimpinannya, GM mampu menunjukkan kebutuhan akan saling memercayai dan saling menghargai di anatara dia, para manajer divisi, dan para pekerja, juga menghargai pekerjaan sebagai sebuah upaya pencapaian tujuan perusahaan RT TV. Menurut pandangan penulis, perilaku-perilaku yang ditunjukkan oleh GM RT TV ini sangat sesuai dengan gaya kepemimpinan team style dalam Managerial Grid Theory dari Blake \& Mouton.

Dalam mengarahakan (directing) para pekerjanya, GM RT TV melakukannya secara lisan dan tulisan, tergantung pada waktu dan tingkat kepentingan pesan yang ingin disampaikan. Bahkan, bila waktu yang tersedia cukup banyak, seringkali GM RT TV melakukan Focus Group Discussion (FGD) dengan para manajer divisi tentang rencana, tujuan, dan tugas-tugas yang harus dilakukan baik oleh para manajer divisi maupun para pekerja. Hal ini dilakukan agar ada feedback yang terbuka dari seluruh peserta FGD, sekaligus juga sebagai bentuk evaluasi rencana kerja sebelumnya. Instruksi secara tertulis dipilih oleh GM RT TV bila pesan yang ingin disampaikan sudah jelas dan sederhana, sehingga tidak akan menimbulkan multi persepsi dari para manajer divisi dan para pekerja. Misalnya saja informasi tentang pengumuman rapat dan undangan makan malam atau buka bersama ketika bulan Ramadhan. 
Dalam manajemen RT TV, wewenang GM ternyata dapat dilimpahkan pada para manajer divisi dan bahkan para pekerja; tergantung pada situasi yang sedang dihadapi. Meskipun ada pelimpahan wewenang, GM RT TV melimpahkan wewenangnya untuk mengelola tugas-tugas di dalam batas-batas yang telah ditentukan, namun wewenang akhir tetap berada pada GM yang memegang wewenang untuk mengelola seluruh kegiatan dan memikul tanggung jawab terakhir.

Dalam manajemen RT TV, salah satu pendelegasian wewenang GM terhadap para manajer divisi terwujud dalam bentuk rekruitmen pekerja. Menurut hasil wawancara, ternyata sistem rekruitmen pekerja di RT TV dilimpahkan pada manajer divisi. Dengan kata lain, bila sebuah divisi membutuhkan pekerja baru, sang manajer divisi akan mendiskusikannya dulu dengan GM, lalu biasanya GM memberikan wewenang pada manajer divisi yang membutuhkan pekerja tersebut untuk melakukan seleksi. Yang jelas, persyaratan minimal untuk menjadi pekerja di RT TV harus memiliki gelar S1, baik itu di divisi program dan produksi, iklan, studio, atau administrasi. Pendelegasian wewenang ini dilakukan karena di dalam manajemen RT TV tidak terdapat divisi HRD atau personalia yang biasanya bertugas untuk menyaring para calon pekerja. Sedangkan pendelegasian wewenang GM terhadap pekerja terwujud dalam bentuk pengambilan keputusan di lapangan. Bila keadaan di lapangan memaksa seorang pekerja untuk mengambil keputusan tanpa terlebih dahulu melapor kepada manajer divisi atau GM, itu boleh saja dilakukan, asalkan ada alasan yang logis dan jelas, disertai laporan yang memadai dan tanggung jawab yang besar dari pekerja.

Berdasarkan pendelegasian wewenang tersebut, bisa dikatakan bahwa manajemen RT TV menganut desentralisasi wewenang, yang merujuk pada konsep pengorganisasian yang memandang bahwa apa yang terjadi di lapangan atau dalam kenyataan seringkali tidak sesuai dengan apa yang dipahami oleh hierarki tertinggi dari sebuah organisasi, oleh karena itu perlu ada pembagian porsi dalam hal pengambilan keputusan dan kebijakan yang menyangkut dengan cara bagaimana organisasi akan dijalankan (Sule \& Saefullah, 2012: 183). Menurut peneliti, desentralisasi wewenang sangat cocok digunakan dalam manajemen RT TV yang cair, karena menurut Terry (2012: 105), desentralisasi wewenang bisa mendorong efektivitas hubungan antar manusia, terdapat kesempatan yang lebih besar untuk mengembangkan dan mengelola organisasi, dapat meningkatkan kerja sama dan membina bagian-bagian dari organisasi, serta bisa menyebarkan resiko-resiko kerugian personal dan fasilitas-fasilitas.

\section{Cara General Manager (GM) Radar} Tasikmalaya TV (RT TV) Memotivasi Para Pekerja

Keberhasilan stasiun penyiaran dalam mencapai tujuannya terkait sangat erat dengan tingkatan atau derajat kepuasan karyawan dalam memenuhi kebutuhannya. Semakin tinggi tingkat kepuasan karyawan, maka 
kemungkinan semakin besar karyawan memberikan kontribusi terbaiknya untuk mencapai tujuan stasiun penyiaran bersangkutan (Morissan, 2011: 162-163). Hal ini tampaknya diperhatikan oleh GM RT TV. GM RT TV menganggap para pekerjanya adalah individu-individu yang aktif, kreatif, inovatif, dan bisa mengaktualisasikan dirinya. Oleh karena itu, motivasi yang seringkali diberikan oleh GM RT TV kepada para pekerjanya tidak selalu berbentuk materi/uang.

Penghargaan personal yang ditunjang dalam situasi komunikasi yang cair dan penuh kedekatan ternyata dapat menambah motivasi para pekerja. Para manajer divisi juga terus berupaya mewujudkan sebuah suasana pekerjaan yang kondusif serta mendukung adanya partisipasi dari para pekerja di divisiya dalam hal bekerja, berinisiatif, dan melakukan pekerjaan secara mandiri. GM RT TV juga memberikan motivasi kepada para pekerjanya dengan cara memberi kesempatan utnuk membuat keputusan atas pekerjaan serta memberikan mereka tanggung jawab.

Dalam memberikan motivasi, GM RT TV menggunakan pendekatan pemuasan kebutuhan. Pada pendekatan ini, maka cara dan suasana kerja ditetapkan mengikuti keterampilan kerja pegawai supaya ada perimbangan antar kepuasan dan kebutuhan, serta hubungan antar anggota kelompok dan pekerjaannya. Tujuannya ialah membangkitkan suatu kemauan untuk mengerjakan tugas, sehingga dapat diselesaikan dengan baik dan memberi kepuasan kepada yang bersangkutan dan perusahaan (Terry, 2012: 131-132).

Selain motivasi dalam lingkup internal yang dilakukan baik itu oleh GM maupun para manajer divisi kepada para pekerja di divisinya, motivasi yang datang dari pihak eksternal pun dilakukan oleh manajemen RT TV. Jika para pekerja dinilai sudah dalam titik jenuh tertinggi dalam bekerja, dan juga sedang terlihat lelah secara fisik dan mental, biasanya manajemen RT TV mengadakan sebuah pelatihan motivasi yang berbentuk hypnotherapy di mana pelatihan tersebut dilakukan oleh sebuah lembaga hypnotherapy. Biasanya pelatihan tersebut dilakukan selama sehari penuh. Tidak hanya para pekerja yang mengikuti pelatihan tersebut, termasuk juga GM dan para manajer divisi.

\section{Jenjang Karier}

Menurut hasil wawancara, jenjang karier di RT TV cukup terbuka dan siapapun bisa meningkatkan kariernya di sini. Kenaikan pangkat atau posisi di RT TV sesuai dengan kebutuhan di setiap bagian. Bila pekerja yang memulai karier dari "bawah" bisa menunjukkan performa yang maksimal dalam bekerja, dibarengi dengan bakat dan determinasi, bukan tidak mungkin jajaran manajerial bisa mempromosikan pekerja tersebut.

\section{SIMPULAN}

Sistem rekruitmen di RT TV dilimpahkan pada manajer bidang masing-masing. Dengan kata lain, bila sebuah bagian membutuhkan pegawai baru, sang manajer akan 
mendiskusikannya dulu dengan GM, lalu biasanya GM memberikan wewenang pada manajer yang membutuhkan pegawai tersebut untuk melakukan seleksi. Produktivitas pekerja di RT TV dinilai berdasarkan karya yang dihasilkannya. Pekerja di RT TV bisa dikatakan produktif apabila ia berhasil memenuhi target perusahaan. Untuk jenjang karir, jenjang karier di RT TV cukup terbuka dan siapapun bisa meningkatkan kariernya di sini. Kenaikan pangkat atau posisi di RT TV sesuai dengan kebutuhan di setiap bagian.

GM RT TV menggunakan pendekatan hubungan kemanusiaan dalam kepemimpinannya. Pendekatan ini sesuai dengan yang dilakukan GM RT TV, di mana ia mengutamakan peranan penting kebutuhan pekerjanya, motivasi, dan hubungan informal yang hangat. Sang GM sadar bahwa para individu di dalam manajemen RT TV bisa bekerja dengan baik apabila ia membangun sebuah hubungan yang baik di antara mereka. GM di RT TV juga menekankan pola kepemimpinan yang demokratis; di mana para pekerjanya bisa menyempaikan pendapat secara terbuka untuk meraih tujuan bersama. Hal ini terwujud dalam gaya kepemimpinannya, cara ia mengarahkan para pekerjanya, sampai pada pendelegasian wewenang yang dilakukannya dengan cara desentralisasi.

Motivasi yang diberikan oleh GM RT TV tidak selalu berwujud materi. Hal ini dilakukan karena GM RT TV menganggap para pekerjanya adalah individu-individu yang aktif, kreatif, inovatif, dan bisa mengaktualisasikan dirinya. Berdasarkan hal tersebut, pendekatan pemuasan kebutuhan dipilih oleh GM RT TV untuk memotivasi para pekerjanya. Sebagai tambahan, manajemen RT TV juga kerap mengadakan sebuah pelatihan motivasi yang berbentuk hypnotherapy di mana pelatihan tersebut dilakukan oleh sebuah lembaga hypnotherapy jika para pekerja sudah mencapai titik jenuh tertinggi.

\section{DAFTAR PUSTAKA}

Ardianto, Elvinaro, dkk. 2007. Komunikasi Massa: Suatu Pengantar. Bandung: Simbiosa Rekatama Media.

Bungin, Burhan. 2011. Penelitian Kualitatif: Komunikasi, Ekonomi, Kebijakan Publik, dan Ilmu Sosial Lainnya (Edisi Kedua). Jakarta: Kencana.

Morissan. 2011. Manajemen Media Penyiaran: Strategi Mengelola Radio \& Televisi. Jakarta: Kencana Prenada Media Group.

Pace, R. Wayne \& Don F. Faules. 2006. Komunikasi Organisasi: Strategi Meningkatkan Kinerja Perusahaan. Bandung: Remaja Rosdakarya.

Rakhmat, Jalaluddin. 2012. Metode Penelitian Komunikasi: Dilengkapi Contoh Analisis Statistik. Bandung: Remaja Rosdakarya.

Severin, Werner J. dan James W. Tankard. 2008. Teori Komunikasi: Sejarah, Metode, dan Terapan di Dalam Media Massa. Jakarta: Kencana Prenada Media Group.

Sugiyono. 2010. Metode Penelitian Kuantitatif, Kualitatif, dan $R \& D$. Bandung: Alfabeta. 
Sule, Ernie Tisnawati dan Kurniawan Saefullah. 2012. Pengantar Manajemen Edisi Pertama. Jakarta: Kencana Prenada Media Group.

Suprapto, Tommy. 2009. Pengantar Teori \& Manajemen Komunikasi. Yogyakarta: MedPress.
Terry, George R. 2012. Prinsip-prinsip Manajemen. Jakarta: Bumi Aksara.

Sutarto. 1987. Dasar-dasar Organisasi. Yogyakarta: Gadjah Mada University Press. 